\title{
Formation of the artistic culture and national intelligence of Buryatiya: general and special DOI:10.31551/2410-2725-2018-4-2-234-252
}

\section{Kirichenko Svetlana Viktorovna}

Candidate of History, senior research associate of the Department of history, ethnology and sociology the Institute of Mongol studies, Buddology and Tibetology of the Siberian Branch of the Russian Academy of Science. Russia, 670047, Ulan-Ude, Sakhjyanova St., 6. IMBT SB RAS. E-mail: I-a-na@mail.ru.

\begin{abstract}
The article examines and analyzes the process of formation and development of the national Buryat intelligentsia, which took place both in the conditions of all-Russian cultural and historical changes and under the influence of local specific conditions. The author emphasizes that the construction of a new national culture was carry out in difficult conditions, in the absence of practical experience, the necessary material base, scientific and professional personnel. In the context of establishing a new ideology based on the priority of the class approach, the development of culture became a matter of state policy. The bourgeois reforms, the development of capitalist relations in the second half of the 19th century contributing to the folding and quantitative growth of the intelligentsia are shown in this article.
\end{abstract}

Keywords: intelligentsia; Buryatia; Russia; cultural construction; professional education; national autonomies.

\section{Бурятиядағы көркем мәдениеттің және ұлттық интеллигенцияның қалыптасуы: жалпы және арнайы}

\section{Кириченко Светлана Викторовна}

тарих ғылымдарының кандидаты, РҒА СБ моңғолтану, буддология және тибетология Институтының аға ғылыми қызметкері. Ресей Федерациясы, 670047, Улан-Удэ қ, ул. Сахьянова к, 6 үй. E-mail: I-a-n-a@mail.ru.

\begin{abstract}
Аңдатпа. Мақалада орыс-мәдени мәдени және тарихи өзгерістер жағдайында және жергілікті ерекшеліктердің әсерінен орын алған ұлттық Бурят зиялы қауымының қалыптасуы мен даму үдерісі қарастырылады және талданады. Автор жаңа ұлттық мәдениеттің құрылысы практикалық тәжірибе, қажетті материалдық-техникалық база, ғылыми және кәсіби маман болмаған күрделі жағдайларда жүргізілгенін атап өтті. Класқа бөлу тәсілінің басымдығына негізделген жаңа идеологияны құру тұрғысында мәдениеттің дамуы мемлекеттің саясатының мәселесі болды. Интеллигенцияның қалыптасуына және сандық өсуіне ықпал еткен XIX ғ. екінші жартысындағы капиталистік қатынастардың дамуы, буржуазиялық реформалар көрсетілген.
\end{abstract}

Кілт сөздер: интеллигенция; Бурятия; Ресей; мәдени құрылыс; кәсіби білім беру; ұлттық автономиялар.

\section{Становление художественной культуры и национальной интеллигенции Бурятии: общее и особенное}

\section{Кириченко Светлана Викторовна}

кандидат исторических наук, старший научный сотрудник отдела истории, этнологии и социологии, Институт монголоведения, буддологии и тибетологии СО РАН. Российская Федерация, 670047, г. Улан-Удэ, ул. Сахьяновой, 6, ИМБТ СО РАН. E-mail: I-a-n-a@mail.ru.

Абстракт. В статье рассмотрен и проанализирован процесс становления и развития национальной бурятской интеллигенции, происходивший как в условиях общероссийских культурноисторических изменений, так и под воздействием местных специфических условий. Автор подчеркивает, что строительство новой национальной культуры осуществлялось в сложных условиях при отсутствии практического опыта, необходимой материальной базы, научного и профессионально-кадрового обеспечения. В условиях утверждения новой идеологии, основанной на приоритете классового подхода, развитие культуры стало вопросом политики государства. Показаны буржуазные реформы, развитие капиталистических отношений во второй половине XIX в. способствовавшие складыванию и количественному росту интеллигенции.

Ключевые слова: интеллигенция; Бурятия; Россия; культурное строительство; профессиональное образование; национальные автономии. 
әоЖ/ УДк 316.4(571.54)

\section{Становление художественной культуры и национальной интеллигенции Бурятии: общее и особенное}

\section{С.В. Кириченко}

Процесс становления и развития национальной бурятской интеллигенции имеет свои особенности, поскольку он происходил как в условиях общероссийских культурно-исторических изменений, так и под воздействием местных специфических условий. Эти условия характеризовались, с одной стороны, воздействием центральноазиатской культуры, буддизма. С другой, влиянием материальной и духовной культуры русского населения. Буддизм, проникший в Бурятию в первой половине XVIII в., внес в бурятское общество свой тип культуры.

Буддийские храмы-дацаны, стали настоящими центрами просвещения. По официальной статистике, в 1917 г. в Бурятии насчитывалось 44 дацана и 15 тыс. лам, 73 дацанских школы, в которых обучались 4 тыс. учащихся (Отчий край 1993: 41-42). Дацаны осуществляли образовательные, воспитательные и другие фрункции, а ламаистское духовенство - самая образованная часть бурятского общества - выступала не только проводником буддийской религии, но и просвещения. Исследователи вполне справедливо относят бурятских священников, знавших буддийскую фрилософию, тибетскую и монгольскую письменность, к первым представителям бурятского интеллектуального слоя (Бильтрикова 2001: 27).

Первые учителя и ученые появились в области буддийской философрии, монгольской и тибетской письменности, литературы, восточной медицины. Дацаны были центрами книгопечатания и школьного образования «по системе 10 средневековых наук», в них издавались книги не только религиозного характера, но также и обширная дидактическая литература: сказки, притчи и т.д. Как отмечала К.М. Герасимова, «с приходом буддизма в Бурятию появляются профессиональные скульпторы, живописцы, зодчие, знатоки восточных языков, переводчики, стилисты, знатоки теории поэзии, изобразительного искусства» (Герасимова 1995: 45). Их отличала особая профессиональная подготовка, а деятельность носила высокоинтеллектуальный характер.

Буряты издавна проявляли интерес к просвещению и образованности. Задолго до открытия первых правительственных училищ и частных школ встречались люди, хорошо владевшие русской и монгольской грамотой, различными специальностями: писари, переводчики, священнослужители, учителя, врачи. Тем не менее, получение образования, как религиозного, так и светского, было затруднено по ряду объективных причин. Европейски образованные люди были редкостью для степной аристократии, колониальная политика центра не предусматривала широкого просвещения населения далеких окраин. Сибирь оставалась краем каторги и ссылки, сырьевым придатком.

Лишь в конце XIX в. бурятская светская интеллигенция представляла собой отдельный отряд образованных людей, хотя и весьма немногочисленный. Благодаря их просветительской деятельности, происходило внедрение в массы народа идей европейского Просвещения,

Работа подготовлена при поддержке гранта РФФИ № 18-09-00630 «Плавильный тигель» социализма: интериоризация советской модели в традиционных сообществах Бурят-Монголии (1920-е-1930-е гг.)». 
знакомство с явлениями духовной культуры стран Европы, испытавших в XVIII-XIX вв. мощный подъем культуры. Среди первых представителей светской бурятской интеллигенции были Д. Банзаров, Г. Гомбоев, Я. Болдонов, внесшие неоценимый вклад в культуру бурятского народа. В своей рукописи «О бурятской интеллигенции», датированной 1908 г., Ц. Жамцарано поименно перечисляет наиболее известных и авторитетных бурятинтеллигентов, стоявших у истоков формирования национальной интеллигенции².

B начале $\mathrm{XX}$ в. в число наиболее образованных представителей народа входили ученые-востоковеды Ц. Жамцарано, Б. Барадин, Г. Цыбиков, политические деятели Б.-Д. Очиров, М.Н. Богданов, Э.Д. Ринчино.

Появление бурятской светской интеллигенции стало результатом влияния русской светской культуры. Одаренные представители бурятского народа получили возможность учиться в университетах Санкт-Петербурга и Казани, работать вместе с выдающимися учеными-востоковедами, наблюдать за социальными явлениями, происходящими в центральной России. Они и стали первыми представителями интеллигенции в европейском понимании. А из среды бурятского духовенства вышли такие выдающиеся деятели, как А. Дор-жиев, Ч. Иролтуев, Р. Номтоев.

Тот фракт, что край был местом каторги и ссылки, также способствовал становлению и развитию национальной интеллигенции. В Прибайкалье и Забайкалье ссылались прогрессивные политические деятели, приносившие сюда идеи борьбы за свободу народа. Не всегда сила идей, которые пытались донести до местного населения политические ссыльные, проникала в их сознание, однако число политически мыслящих бурят постепенно увеличивалось. Эти люди хорошо осознавали, что судьбы малых этносов, так или иначе, определяют более многочисленные и могущественные народы. Монгольские племена оказались между двумя гигантами - Россией и Китаем, а их земли стали своеобразным буфером. Бурятия вступила на путь неизбежного интегрирования в российское общество, в его духовность, меняя на ходу старые принципы и традиции, приобретая ускорение общего темпа жизни.

Появлению первых школ в Бурятии способствовали реформы Петра І. Еще в 1725 г. царским указом при Иркутском Вознесенском монастыре была открыта первая в Восточной Сибири так называемая «мунгальская» школа «для обучения сибирских отроков китайскому и монгольскому языкам, в видах лучшего сближения с соседями», для распространения православной веры. В 1727 г. при школе было открыто отделение для обучения славяно-русской грамоте детей, принадлежавших ко всем сословиям.

Общеобразовательные школы появились во второй половине XVIII в. В 1789 г. правительство Екатерины II провело новую реформу учебных заведений России, которая предусматривала два типа учебных заведений: главные и малые народные училища. Первые из них открывались в губернских городах, а вторые - в уездных. В Сибири они появились позже, чем в центре. Первое главное народное училище было открыто в Иркутске 22 сентября 1789 г.; второе малое народное - в Верхнеудинске 13 февраля 1793 г., в 1806 г. оно было преобразовано в уездное училище.

В 1804 г. была произведена новая реформа в области просвещения, и издан «Устав учебных заведений». В 1806 г. открывается вторая бурятская школа -

\footnotetext{
${ }^{2}$ ЦВРК (Центр восточных рукописей и ксилографов) ИМБТ СО РАН, 1908. ф. 6, оп. 1, д. 9. Жамцарано Ц. О бурятской интеллигенции.
} 
Онинское приходское училище (при Хоринской степной конторе). Позднее Троицкосавское уездное (1812) и ряд приходских училищ: Идинское (Бохан) и Тункинское (1816), Селенгинское (1818), Аларское (1830), Агинское, Нукутское (1842) и другие. Знаменитая Троицкосавская войсковая русско-монгольская школа была открыта в 1832 г. Развитие сети светских учебных заведений было продиктовано реформами 1860-1870-х гг., утверждением новых программ реорганизации школ. Появлялись различные типы профессиональных учебных заведений: реальные, коммерческие, ремесленно-технические и промышленные училища, учительские и духовные семинарии и другие, возникновение которых было обусловлено дальнейшим развитием торговли и промышленности в крае. В этих учебных заведениях училась и бурятская молодежь. В целом ремесленное и профессиональное образование в Восточной Сибири было развито слабо. Однако существовавшие профессиональные учебные заведения в крае имели большое значение для культурного развития населения, особенно нерусских народов: бурят, эвенков, якутов и других.

В 1860-е гг. были предприняты первые шаги в развитии женского образования. Начальные школы стали делиться на мужские, женские и школы совместного обучения. Было положено начало и среднему женскому образованию. На базе некоторых женских школ в городах стали открываться женские прогимназии, в том числе Иркутская (четырехклассная), Троицкосавская (пятиклассная) и Верхнеудинская (трехклассная) прогимназии и две гимназии.

Вместе с тем, база светского образования была довольно ограниченной. Причина преимущественного обучения бурятских детей в дацанских школах заключалась в том, что в обычных государственных учебных заведениях европейского типа обучение велось на русском языке, не было нужных учебников и учебных пособий. При почти поголовном незнании русского языка населением бурятских ведомств Забайкалья учеба в светских школах была затруднена. В дацанских же школах обучение и воспитание велось на бурятском и монгольском языках, изучались тибетский и санскрит. Поэтому роль религиозного фрактора в формировании национальной интеллигенции Бурятии была достаточно высока. Кроме того, русское православное духовенство в целях христианизации бурят и подчинения их русскому влиянию прибегло к организации особых школ духовного ведомства, получивших название миссионерских. Первая миссионерская школа была организована в 1862 г. при Посольском монастыре в Забайкалье. В 1903 г. бурятское православие в Иркутской губернии имело 59 миссионерских и духовных школ, в которых обучалось 1400 человек. В это же время стали учреждаться и церковно-приходские училища.

История становления национальной культуры народа не ограничивается сорерой его происхождения, поэтому понятие «бурятская культура» не вполне совпадает с понятием «культура Бурятии». Культура Бурятии, кроме бурятской, охватывает культуры других народов, исторически составивших население края. Искусство любого народа активно и плодотворно развивается в том случае, если оно питается не только духовным богатством своей нации, но и обогащается инонациональными культурными ценностями.

История развития Бурятии более трех столетий неразрывно связана с многонациональной культурой российского государства, формировавшейся усилиями многих народов. Во второй половине XIX в. в Иркутске, где уже имелись значительные силы русской интеллигенции, был открыт профрессио- 
нальный театр. Он имел в своей труппе актеров, приехавших из Центральной России, в частности, из Москвы и Петербурга. В 1850-е гг. в Иркутске работал актер Малого театра А. Рассказов, в 1870-80-е гг. - В. Глухарева-Каратыгина из Петербурга, П. Мартынов, А. Огарев, Е. Горева, а также известные провинциальные актеры Пузинский, Арди-Светлова, Карамазов (Маляревский 1957: 45-82). Наличие в Иркутске крепкого профессионального театрального коллектива не могло не отразиться на развитии любительского искусства и общем повышении интереса к театру в Бурятии.

Несмотря на то, что Бурятия была одной из довольно отсталых окраин Российской империи, еще до революции 1917 г. Верхнеудинск превратился в культурный центр Забайкалья, имевший школы, музеи, частные библиотеки, периодические издания. В связи со строительством Транссибирской железнодорожной магистрали город быстро рос, увеличивалось население, появились новые школы и гимназии, выросло число интеллигенции. По свидетельству старожила Верхнеудинска, известного врача М.В. Танского, в 1880-е гг. в городе систематически ставились любительские спектакли в помещении общественного собрания, где была оборудована сцена. «Преимущественно это были пьесы А.Н. Островского, ставились они любительской группой из местной интеллигенции» (Танский 1963: 24). Ярким событием в культурной жизни города стали гастрольные выступления выдающейся русской актрисы В.Ф. Комиссаржевской в 1909 г.

Тяга к просвещению среди бурятской молодежи была поддержана прогрессивной русской интеллигенцией Иркутска, проводившей большую просветительскую работу. Одной из фрорм этой деятельности были этнографические вечера, положившие начало любительскому бурятскому театру. На одном из таких вечеров в 1908 г. в Иркутске была разыграна первая бурятская пьеса «Ухэл» («Смерть»), написанная учащимся Иркутской учительской семинарии Д. Абашеевым.

Подобные этнографические вечера, регулярно устраиваемые в 1911-1914 гг. Обществом вспомоществования учащимся бурятам, организованным при Восточно-Сибирском отделении Русского географического общества, сыграли значительную роль в развитии бурятской драматургии и театра.

Бурятская интеллигенция как социальная группа начала формироваться в XIX в., когда рост капиталистических отношений и совершенствование государственного управления потребовали увеличения численности работников умственного труда и создания системы народного просвещения. Неблагоприятные условия, в которых проходило ее формирование (низкий уровень социально-экономического развития края, отдаленность от культурных центров, господство религии в духовной жизни народа, поддерживаемые царской политикой, консервировавшей социальную структуру бурятского общества, характеризующуюся преобладанием крестьянства, в том числе кочевого, отсутствием промышленной буржуазии и пролетариата, многочисленности духовенства) определили ее мелкобуржуазную природу, близость к народу; естественный отбор при обучении, пополнение лучшими представителями народа; престижность образования, дававшего возможность повышения социального статуса.

Буржуазные реформы, развитие капиталистических отношений во второй половине XIX в. способствовали ее складыванию и количественному росту. Активная просветительская деятельность, развернувшаяся под руководством русских ученых и деятелей просвещения, сочетание европейского образования с традиционным духовным наследием в мировоззрении, высокие личные 
качества - все это обеспечило высокий авторитет ее представителей у населения.

В России одним из важнейших проявлений освободительного движения во второй половине XIX в. была просветительская деятельность интеллигенции. Эта тенденция не обошла стороной и бурятский народ, где в конце века зародилось реформаторское и просветительское движение, которое способствовало выводу нации на качественно новый уровень образованности и просвещенности.

В начале XX в. перед бурятским населением остро встала проблема перспектив дальнейшего развития. Социально-политическое лидерство интеллигенции было обусловлено особенностями исторического развития бурятского народа. Став во главе национального движения как наиболее активная, образованная и авторитетная общественная сила, интеллигенция выдвинула из своих рядов блестящую плеяду политических и культурных деятелей, предложивших различные варианты достижения общих целей движения. Неприятие капитализма, сильное влияние русской общественнополитической мысли - декабризма, народничества, областничества обусловили принадлежность большинства интеллигентов к левосоциалистическому, народническому крылу национального движения, вскоре распавшегося на два течения в связи с исторически сложившимся разделением этнической Бурятии на две этнокультурные среды - сферу русско-православного влияния в Прибайкалье и восточно-ламаистского - в Забайкалье.

Как отмечает Т.Д. Скрынникова, «бурятская национальная интеллигенция включилась в общероссийский контекст национального движения, а наивысшую активность в нем проявила наиболее образованная часть общества деятели народного образования, сформировавшие союз «Знамя бурятского народа» и «Общество просвещения бурят», целенаправленно ориентировавшие свою деятельность на возрождение традиционных этнических форм культуры, прежде всего, буддизма, обладавшего высокими интеграционными возможностями» (Бурятская этничность 2003: 42). Если этой частью бурят модернизация воспринималась как угроза существования этноса, и выход виделся в сохранении и укреплении традиции, то движение, идейным представителем которого был М.Н. Богданов, не оформленное организационно, пыталось учесть, прежде всего, изменения российской действительности и их влияние на жизнь бурятского этноса.

М.Н. Богданов, «рационально объяснявший результаты русификации и модернизации, был ярким выразителем идей о необходимости вступления бурят на путь модернизации и освоения уже наработанного на этом пути западным сообществом (через русскую культуру) и отказа от традиционных фрорм жизни. Он писал: «Пока мы оживим застывшую монгольскую литературу и дойдем до создания «шедевров национального художественного творчества», не успеет ли уже раздавить нас всемогущий бог западноевропейской культуры - капитал, который с водворением в России новых форм жизни, мощными шагами пойдет вперед? Нужно помнить, что мы живем не в эпоху средневековья, когда каждая маленькая национальная группа могла жить внутри своей ячейки совершенно изолированно от внешнего мира, а в XX в., когда процесс капиталистического развития разрушает почти все национальные различия, какими бы китайскими стенами они не отгораживались. Спасение наше не в том, чтобы дрожать над выдуманными нами национальными особенностями, а в возможно скором и прочном 
усвоении цивилизации. Для этого необходим русский язык...» (Бурятская этничность 2003: 43).

Выделяя эти идентификационные практики, Т.Д. Скрынникова отмечает, что именно они определяли активное конструирование идей национальнокультурной идентичности бурят. На мой взгляд, в результате их взаимодействия и последующего культурного развития в регионе возникла так называемая бинациональная культура, национальный компонент которой, с одной стороны, придает уникальность и силу общероссийской, а с другой выделяет то, что присуще каждому народу.

Что касается течений внутри групп бурятской интеллигенции, то надо отметить, что существовало еще одно - «партия прогрессивных бурят» во главе с Ч. Иролтуевым, Г.Ц. Цыбиковым, выражавшая интересы нарождавшейся буржуазии и выдвигавшая требования конституционнодемократического характера, принимая реформы 1901-1903 гг.

Все три течения сходились на необходимости сохранения и совершенствования общинных институтов, уравнительного землепользования, что, с одной стороны, свидетельствовало о непонимании объективного характера развития капитализма, политическом идеализме, а с другой - об идейной близости и возможности объединения.

Накануне революции бурятская национальная интеллигенция представляла собой вполне сложившуюся группу образованных людей, составлявших элиту бурятского народа, осознававшую свое предназначение, отстаивающую интересы своего народа. Малочисленность интеллигенции, сложившаяся политическая обстановка способствовали совмещению ее представителями различных видов деятельности: профессиональной, общественно-политической и творческой.

На этом этапе наблюдаются первые опыты создания реалистических художественных произведений. Наибольшее развитие ввиду отсутствия общенациональной письменности и издательской базы, неграмотности масс получил самый доступный вид искусства - самодеятельный театр, улусная драматургия. Как уже отмечалось, в Иркутске десятки самодеятельных трупп из учителей, бывших студентов и учащихся учебных заведений города ставили пьесы русских классиков. В 1917 г. Ч.-Л. Базароном и Д.-Р. Намжилоном был основан быстро завоевавший популярность у населения Агинский народный театр. В Верхнеудинске возникли новые объединения любителей: комсомольско-молодежные, профсоюзные, армейские, работал постоянный коллектив художественной самодеятельности при областном отделе народного образования. Появились новые виды театральных представлений: спектакль-диспут, спектакль-митинг, устраивались и литературные суды над героями драматических произведений. В рукописных журналах бурятских студентов Иркутска «Очин», «Дольен», «Товарищ» в 1917-1918 гг. периодически выходили стихи молодых поэтов Д. Жабона, Ц. Дашиева, М. Гордеева, А. Балдаева, П. Шодонпилова, в которых преобладали агитационномассовые мотивы. В этот период происходит становление бурятской живописи, связанное с творчеством первых бурятских художников А.Е. Хангалова, Ц.С. Сампилова, Р.С. Мэрдыгеева.

Период установления советской власти характеризуется политическим и идейным размежеванием интеллигенции, острейшей борьбой бурятских автономистов с местными Советами, бурятской группой большевиков и традиционалистами. Группа бурятских интеллигентов-большевиков и левых эсеров (М. Сахьянова, С. Николаев, Ф. Осодоева, Г. Данчинов, Е. Золхиева, В. 
Трубачеев, М. Ербанов, Н. Махочкеев, Д. Убугунов, И. Рампилов и др.), оформившаяся в начале 1918 г., развернула пропаганду идей советской власти среди бурятского населения, решительно выступила за создание единого управления - Советов депутатов - для всего населения, считая неизбежной быструю ассимиляцию бурят, и вступила в открытую дискуссию с национал-демократами.

В условиях угрозы ликвидации достижений многолетней работы по национально-культурному возрождению бурят частное совещание бурятских общественных деятелей, состоявшееся 17 марта 1918 г. в Чите, решило создать «Союз бурятской интеллигенции», который «должен преследовать цели объединения всей бурятской интеллигенции на социалистической платформе», «влить в определенное организационное русло» стремление бурятских масс к социалистическим преобразованиям (Гирченко 1927: 37). Но замысел не имел воплощения, советская власть укрепляла свои позиции. Осознав тщетность примиренческой политики, Бурнацком решил «признать Советскую власть как реально существующую, и делегировать в советские организации своих представителей» (Гирченко 1927: 38).

Приняв на себя всю полноту власти на бурятской территории и произведя внешнее реформирование местного самоуправления и суда, Бурнацком сумел добиться их признания областным Советом 3 июля 1918 г. «публичноправовыми учреждениями Советской власти, действующими на территории бурят автономно», а также решения о необходимости созыва учредительного съезда бурят и совместной выработки окончательного проекта бурятской автономии (Батуев 1993: 49).

В первом полугодии 1918 г. произошло политическое размежевание бурятской интеллигенции, в еe среде появилась новая просоветская группировка, претендовавшая на руководство; наблюдался переход части интеллигенции от прямой оппозиции к сотрудничеству с советской властью и участию в еe социально-культурных преобразованиях, особенно в Прибайкалье; началась совместная работа Бурнацкома и Советов по созданию проекта автономии. Сотрудничество было прервано начавшейся в июлеавгусте 1918 г. иностранной интервенцией и гражданской войной.

Большевики, левые эсеры и сочувствующие им частью спаслись от преследований за пределами Бурятии, некоторые ушли в подполье. Какая-то часть интеллигенции приняла новый режим, отменивший декреты советской власти о национализации и конфискации частной собственности, поддержавший ламаистскую церковь и национальные структуры (Бурнацком был слит с эмигрантским бурятским отделом «правительства Забайкальской области» и преобразован в Бурнардуму в сентябре 1918 г.). Большая часть интеллигенции с самого начала составила оппозицию новой власти, отказавшись от участия в работе ее органов. Так, из состава Бурнацкома вышли Н.В. Преловский, Д.Б. Бадмажапов, Б.Р. Рабданов, М.Н. Богданов.

Тяжелое положение советской России, находившейся в кольце фронтов, неопределенность будущего бурятского народа в составе России способствовали тому, что члены Бурнардумы в конечном счете склонились к идее объединения монгольских народов в рамках единого нейтрального государства, в котором бурятские национал-демократы рассчитывали занять лидирующие позиции (что явствует из письма Э.-Д. Ринчино, адресованного Д. Сампилону) (Ринчино 1994: 22-24); участию в общемонгольской конференции представителей Барги, Монголии и Бурятии, состоявшейся в феврале 1919 г. в 
Чите при содействии японских милитаристских кругов, пытавшихся усилить свое влияние в регионе.

Восстановление дореволюционных порядков, разгон профсоюзов, преследование культурных организаций, развал сети школ, мобилизация молодежи и бурят-казаков в Белую армию, репрессии семеновцев вызвали резкую смену настроений бурятских интеллигентов, первоначально лояльных или нейтральных колчаковско-семеновскому режиму, выразившуюся в отказе от политической деятельности (в начале 1919 г. Г.Ц. Цыбиков, Ц.Ж. Жамцарано и Б.Б. Барадин вышли из состава Бурнардумы, занявшись научной работой), от исполнения служебных обязанностей и уклонении от призыва в армию. А в начале 1920 г., после казни семеновцами М.Н. Богданова, Бурнардума заявила о самороспуске, призвав население к борьбе с атаманом Семеновым.

Но даже в эти тяжелые годы, когда были почти уничтожены плоды трудов по национализации школы в 1917-1918 гг., работники образования продолжали свою работу. В 1918-1920 гг. В Агинском функционировали высшие двухгодичные педагогические курсы, слушатели которых Ж. ЖамцараноПилунова, Л. Линховоин, А. Аюрзанайн, Ж.-Д. Мункин, Д. Найдано, Б. Балдано и др. - повышали свою квалификацию и участвовали в работе Агинского народного театра, перешедшего к постановке многоактных пьес, таких как «Обновление», «Тяжелая жизнь» Д.-Р. Намжилона, «Бурятские нойоны прошлого» Б. Барадина. Начинает свой творческий путь X. Намсараев, написавший в 1918-1920 гг. пьесы «Темнота» и «Оракул Дамби».

Освобождение Прибайкалья и Забайкалья Красной Армией и партизанами, образование 6 апреля 1920 г. демократической Дальневосточной Республики (ДВР) создало условия для возвращения лидеров национальной интеллигенции к политической деятельности, нового подъема автономистского движения, активизации общественно-политической мысли. Как справедливо считает Т.М. Михайлов, с этого времени начинается новый этап в развитии, как бурятского этноса, так и его культуры (История и культура бурятского народа 1999: 217).

Усилия бурятских автономистов в ДВР увенчались образованием 12 февраля 1921 г. Бурят-Монгольской автономной области, состоявшей из чисто бурятских по этническому составу аймаков и хошунов, получившей самостоятельность в вопросах суда, административно-хозяйственной и культурно-национальной жизни. Создание БМАО ДВР ускорило темпы строительства бурятской автономии в России, затруднявшегося тем, что и без того немногочисленные кадры интеллигенции Прибайкалья заметно поредели в связи с отправкой части их на учебу в Москву (М. Сахьянова, С. Николаев, Ф. Шулунов, А. Маркизов) и на работу в ДВР (В. Трубачев, И. Ченкиров, К. Ильин). Значительная группа во главе с М. Амагаевым была отправлена в БМАО ДВР, где сумела отстранить национал-демократов от руководства. Часть националдемократов, в том числе Ц. Жамцарано и Д. Сампилон, перенесла свою деятельность в Монголию, где, заняв ключевые посты в руководстве, пыталась реализовать неосуществленные в Бурятии замыслы. Другие - Г. Цыбиков, Б. Барадин, П. Дамбинов - остались на родине, включившись в культурное строительство. Таким образом, «старая» интеллигенция утратила политическое лидерство, перешедшее к новому поколению, коммунистам, возглавившим экономическое и культурное развитие бурятских автономий.

В период сосуществования двух автономий многое делалось для сохранения национально-культурной общности населения двух областей, проявилась тенденция к унификации системы образования, просвещения, 
проводились общедемократические преобразования в области культуры, заложившие основу для создания бурятской социалистической культуры. Эту работу возглавил Центральный Совет по культурным делам бурят РСФСР и ДВР под председательством М.Н. Ербанова, а также Бурятский ученый комитет (Буручком), созданные летом 1922 г. Этот период стал важным для интеллигенции в определении ее позиции. Большинство интеллигентов пошло на сотрудничество с советской властью, считавшей за благо использовать их знания и опыт. В первую очередь, учителя, с энтузиазмом занявшиеся налаживанием школьного дела, включившиеся в культурно-просветительскую работу, ликвидацию неграмотности (в 1923 г. насчитывалось 164 учителябурята) (Соктоев 1961: 9). Открывались школы для взрослых, избы-читальни, народные дома, красные юрты, школы бурятской молодежи. Обучение велось на двух языках: русском и бурятском, что создавало неоспоримое преимущество для обучающихся в отличие от школ старого типа. Но грамотность на старомонгольском языке не признавалась, и это сыграло отрицательную роль в последующих переписях при оценке уровня грамотности бурятского населения.

В 1925 г. в Бурятии фрункционировало 188 ликпунктов с 5627 учащимися, из них в аймаках с бурятским населением 86, русским - 98, других национальностей - четыре. Работали 19 хотонных школ ликвидации неграмотности, в которых обучалось 426 человек. Экстренные меры, предпринятые властями, способствовали улучшению обстановки. Если в 1920 г. грамотность населения Бурятии составляла $21,7 \%$, в том числе бурят 15,3\%, то, по данным переписи 1926 г., она поднялась соответственно до 34,0 и $27,0 \%$. Грамотность женщин за эти годы повысилась с 8,8 до 17,3\%, в том числе женщин-буряток - с 4,2 до 10\% (Социалистическое строительство Бурятии...1933: 103).

Новый подъем переживала и художественная самодеятельность. Вернулись к активному творчеству Солбонэ Туя (П. Дамбинов), выпустивший в 1922 г. первый в истории бурятской поэзии сборник стихов «Цветостепь»; Д. Намжилон, написавший «Быт бурятских аршанщиков». Выходят в свет рассказы и очерки Г.Д. Нацова, М. Трубачева, Б. Барадина. Из произведений драматургии пользовались успехом пьесы «О бедных и богатых» А. Тороева, «Ученье - свет, а неученье - тьма» И. Дадуева, «Старик Барбадай» и «Революция» X. Намсараева. Наибольший общественный резонанс вызвали исторические драмы Б. Барадина «Чойжид-хатан» и «Великая сестрица шаманка», поставленные на сцене Агинского народного театра. Получили признание картины Ц. Сампилова.

К сотрудничеству с советской властью склонялась и прогрессивная часть ламаистского духовенства, возглавляемая А. Доржиевым, чьи идеи реформизма, тождественности положений буддизма и марксизма-ленинизма были утверждены I Собором буддистов в 1922 г. (Андреев 1992: 31).

С вхождением ДВР в состав РСФСР 14 февраля 1922 г. руководство автономных областей, несмотря на сопротивление Сибирского Дальневосточного бюро ЦК РКП(б), настояли на образовании единой БурятМонгольской АССР (30 мая 1923 г.). С созданием собственной национальной государственности у бурятского народа появились необходимые и благоприятные условия для развития на качественно ином уровне своей национальной культуры.

Как отмечает А.А. Елаев, «государственность призвана была выступать гарантом и своеобразным инструментом создания, сохранения и защиты новой 
национальной культуры. В свою очередь, национальная культура являлась основной целью и должна была служить своего рода «оправданием» образования национальной автономии и государственности бурятского народа. Историческая роль бурятской государственности состояла в том, что она была инструментом фоомирования новой этносоциальной общности - бурятской социалистической нации» (Елаев 2000: 191).

Строительство новой национальной культуры осуществлялось в сложных условиях, при отсутствии практического опыта, необходимой материальной базы, научного и профессионально-кадрового обеспечения. В связи с этим задачи и направления преобразований становились предметом острых дискуссий и споров 1920-х гг. Необходимо было, прежде всего, разобраться с культурным наследием, где были тесно переплетены религиозные, светские, демократические элементы. В условиях утверждения новой идеологии, основанной на приоритете классового подхода, развитие культуры стало вопросом политики государства. Взятый на вооружение партии лозунг строительства новой культуры, социалистической по содержанию и национальной по форме, вызывал множество вопросов у практических работников на местах.

Основные задачи в области национально-культурного строительства были сфрормулированы на пленуме обкома ВКП(б) 25 августа 1925 г. В тезисах обкома по «культурно-национальному строительству Бурятии» (Бурятская организация КПСС 1987: 137) отмечалось наличие различных подходов к вопросу о национальной культуре. Как и в начале века, один подход заключался в отрицании возможности развития бурятской культуры как таковой, другой же отстаивал необходимость обособленного от русской и европейской культуры развития на основе традиционности. В тезисах была дана критика этих подходов и подчеркнута необходимость развития бурятской национальной культуры - языка и письменности, литературы, искусства - на основе укрепления ее социалистического содержания, путем восприятия всего передового из других культур, прежде всего, культуры русского народа.

В сентябре 1926 г. тезисы обкома были обсуждены на первом республиканском культурно-национальном совещании, в котором приняли участие около девяноста деятелей культуры Бурятии, а также представители научных учреждений Москвы, Монголии и Восточной Сибири. С докладом выступил председатель СНК республики М. Ербанов, по итогам совещания было принято развернутое постановление (Цыбиков, Барадин, Дамбинов 1926; Ербанов 1926).

В связи с особой актуальностью проблем развития языка и письменности совещание приняло по этому вопросу специальную резолюцию, в которой отмечалось, что «вопрос о повышении языковой культуры бурят-монгольского народа должен быть разрешен не в масштабах одних бурят-монголов, а в масштабе общемонгольском» ${ }^{3}$. Исходя из этого, за основу бурятского литературного языка и письменности были взяты халхаское наречие монгольского языка и старомонгольский алфравит. Как известно, до революции бурятская национальная культура, особенно в восточных аймаках, оставалась частью общемонгольской культуры, базировавшейся на старомонгольской письменности.

Первыми школьными учебниками по бурятскому языку стали «Грамматика бурят-монгольского языка» Б. Бадмаева и «Грамматика письменномонгольского языка» Н. Поппе. Широкое внедрение нового литературного

${ }^{3}$ Резолюция совещания 1926 г. (РО ИМБТ СО РАН, док. 434.9). 
языка на основе монгольской письменности сдерживалось объективными трудностями. Так, в западных аймаках республики в силу исторических условий монгольская письменность и язык не имели широкого распространения. В восточных же аймаках сказывалось отсутствие квалифицированных педагогических кадров и учебно-методической литературы. Но, несмотря на большие трудности, к 1930 г. был обеспечен перевод обучения на родной язык по всем предметам в школах 1-й ступени.

Внедрение старомонгольского письменного языка оказало заметное влияние на становление бурятской профессиональной литературы, издательского дела и печати, были заложены основы стилистики бурятской художественной прозы и поэзии. На основе этой письменности создавались первые республиканские периодические издания на бурятском языке, такие как газета «Буряад-монголуун унэн», журналы «Уран угын чимэг», «Соелун хубисгал» и др. (Дондуков 1998: 146). В этот период делопроизводство в органах государственной власти и других учреждениях велось, наряду с русским языком, на старомонгольской письменности.

«Монгольская» ориентация проявилась не только в реформировании языка и письменности, она была в целом характерна для национальнокультурного строительства в Бурятии в 1920-е гг. Идейно обосновали эту линию и попытались воплотить в практику культурно-национального строительства представители бурятской интеллигенции «первой волны» Базар Барадин, Гомбожаб Цыбиков, Цыбен Жамцарано и другие. Эта линия была поддержана руководством республики и, в первую очередь, председателем Совнаркома М. Ербановым. «Монгольская» ориентация развития бурятской культуры в то время еще была возможна потому, что отвечала установкам Коминтерна на развитие мировой революции в сопредельных странах Центральной Азии и роли Бурреспублики как «форпоста социализма на буддийском Востоке».

Ведущую роль в реализации задач культурной революции сыграл БурятМонгольский ученый комитет. Возглавил ученый комитет Б. Барадин, являвшийся одновременно наркомом просвещения; его членами стали известные бурятские ученые и просветители, такие как В. Гирченко, Ц. Жамцарано, Г. Цыбиков. С момента образования республики Буручком развернул активную деятельность. В нем сконцентрировались имевшиеся в наличии научные силы, и была сосредоточена вся научно-исследовательская работа. За короткое время в тесном контакте с учеными Российской Академии наук, Ленинградского и Иркутского университета Буручкомом были созданы основные фонды научной библиотеки и рукописного отдела, развернута работа по сбору материалов устного народного творчества, языка, истории, организован перевод на бурятский язык научной, учебной и политической литературы. Под эгидой Буручкома возобновили свою работу Троицкосавский и Верхнеудинский краеведческие музеи и созданное местное отделение Географического общества.

Основные усилия ученого комитета были сосредоточены на изучении истории Бурятии. С этой целью при поддержке руководства республики с 1924 г. по 1933 г. стали издаваться журналы «Жизнь Бурятии», «Бурятиеведение», «Культура Бурятии», «Бурятоведческий сборник» и «Просвещение Бурятии», освещавшие актуальные вопросы экономики, истории, археологии, географии и этнографиии.

В апреле 1924 г. было создано Бурят-Монгольское научное общество имени Д. Банзарова с филиалами в аймаках, объединившее вместе с 
Буручкомом усилия и энтузиазм молодой бурятской интеллигенции в изучении края и пропаганде исторических знаний среди населения республики. В работе научного общества принимали участие Г. Цыбиков, В. Гирченко, Ф. Кудрявцев, Г. Дебец, П. Хороших, М. Азадовский и др.

Несмотря на то, что революция облегчила доступ к культурным ценностям для всего народа, вовлекая в этот процесс и крестьян, в 1920-1930-е гг. очень остро стояла проблема кадров. Принципы партийной работы в национальных республиках и областях получили развитие в решениях XII съезда РКП(б). Особое значение придавалось фоормированию коммунистических кадров в национальных республиках и областях, комплектованию в них органов по преимуществу из местных людей, знающих язык, быт, нравы и обычаи коренных народов, изданию массовой партийной литературы на местных языках, усилению партийно-воспитательной работы среди нерусских народов, в особенности среди молодежи и женщин (КПСС в резолюциях и решениях... 1953: 716-718).

На расширенном совещании секретарей уездных и аймачных комитетов республики, состоявшемся 13 сентября 1923 г., основное внимание было уделено укреплению областной партийной организации, подбору, расстановке и воспитанию кадров. Участники совещания говорили о необходимости наряду с расширением подготовки национальных кадров привлекать к работе лояльно настроенных к советской власти представителей местной интеллигенции. «Привлечение лояльных элементов из местной интеллигенции к активной советской работе в условиях действительности Бурятской республики», говорилось в решении совещания, - «имеет чрезвычайно важное значение. Bсе советские и партийные органы обязаны на это обратить как в центре, так и на местах самое сугубое внимание» ${ }^{4}$.

Кроме привлечения старой интеллигенции возникла настоятельная необходимость в средних специальных учебных заведениях для подготовки специалистов на месте. В связи с этим было открыто несколько техникумов и вузов. Был взят курс на так называемую «коренизацию» местных органов власти и управления, увеличение в их составе представителей бурят. Контроль над ходом «коренизации» в национальных образованиях со стороны центральных государственных органов был усилен к концу 1920-х - началу 1930-х гг. В 1932 г. Президиум ВЦИК принял специальное постановление, в котором еще раз были подчеркнуты государственная важность и политическое значение этой работы и определены дальнейшие задачи по ее продолжению (Санжиев 1971: 161). К концу 1930-х гг. был сделан громадный шаг по привлечению представителей бурятского населения к государственному управлению. И это, несмотря на то, что план «коренизации» был выполнен всего на $50 \%$. Этот процесс по методам и срокам его осуществления был во многом искусственным, однако в его ходе решилась важная для жизнедеятельности республики задача подготовки национальных кадров. В целом в ходе культурной революции был дан мощный импульс для развития бурятской культуры.

Однако в конце 1920-х гг. значительно осложнилась международная обстановка. В июле-ноябре 1929 г. на восточных рубежах страны на Китайской Восточной железной дороге (КВЖД) произошел давно назревавший вооруженный конфликт, повлиявший на внешнюю и внутреннюю политику страны. Политическое значение Бурреспублики уже стало оцениваться не через призму мировой революции как «форпоста социализма на буддийском

${ }^{4}$ ГАРБ, ф. П-1, оп. 1, д. 34 , л. 34. 
Востоке» и «плацдарма мировой революции», а в связи с той опасностью, какую она могла представлять как национальное образование, занимающее приграничное положение в случае возникновения внешней угрозы.

Эти обстоятельства наряду с объективными трудностями, а также некоторыми ошибками руководства БМАССР в хозяйственном, государственном и национально-культурном строительстве все больше вызывали у Центра опасения и склоняли его к ужесточению контроля над всеми процессами, происходившими в республике. Одной из первых мер по усилению контроля было постановление ЦК ВКП(б) «О состоянии и работе Бурят-Монгольской партийной организации», принятое по отчету Буробкома ВКП(б) 27 мая 1929 г. В нем были отмечены достижения парторганизации, но значительно большее внимание было уделено допущенным в ее деятельности недостаткам. ЦК, который руководствовался в то время тезисом об обострении классовой борьбы, потребовал решительных мер против усилившихся проявлений великодержавного шовинизма, панмонголизма и бурятского национализма. Подверглась критике как ошибочная «монгольская» ориентация развития бурятской культуры, объявленная реакционной, «феодальнотеократической». Органами НКВД было инспирировано дело о так называемой контрреволюционной, шпионской, «панмонгольской» организации, ставившей целью создание «великого монгольского государства» под эгидой Японии. По этому делу были репрессированы, а позд-нее расстреляны видные представители национальной бурятской интеллигенции - Ц. Жамцарано, Б. Барадин, Э.-Д. Ринчино, С. Ширабон, П. Дамбинов (Солбонэ Туя), И. Дампилон, Д. Ардин, Б. Дашидондобэ, Б.-М. Ванданов, Д. Мункин и другие (Басаев, Ербанова, Ербанов 1989: 195). Репрессии затронули все слои населения, независимо от национальности, и сопровождались широкомасштабной пропагандистской кампанией против «врагов народа».

Объектом открытой борьбы стала церковь. Меры властей по подрыву экономической основы существования буддийской церкви, антирелигиозная пропаганда, возведенная в ранг государственной политики, привели к значительному ослаблению церковной организации и усилению раскола внутри нее. В начале 1920-х гг. между офрормившимися двумя течениями внутри буддийской церкви - консерваторами и обновленцами - развернулась борьба, продолжавшаяся до конца 1920-х гг. В основе кризиса и раскола духовенства лежали политические мотивы - отношение к социалистическим преобразованиям. Консерваторы связывали воедино обновленческую рефрорму и мероприятия Советской власти, обвиняя обновленцев в сотрудничестве с ней.

Однако парторганами республики буддийская церковь со всеми еe течениями рассматривалась как «организованная агентура бурятского кулачества, его политическая и идеологическая сила», поэтому предпринимались меры по развертыванию борьбы с ламством широким фронтом. Уже с 1929 г. обновленческое движение перестает существовать, как и буддийская церковь в целом как организация. С середины 1930-х гг. такой же участи подверглись и православные храмы, а также иудейские синагоги и польские костелы.

С ликвидацией церкви был устранен противостоящий партии духовный институт. Кроме того, подверглись ревизии и гонениям многие традиционные духовные ценности бурятского народа, объективно имевшие религиозные корни. Под фрлагом утверждения прогрессивных норм социалистической культуры в 1930-е гг. было развернуто наступление на традиционный быт 
бурятского общества. Вековые обычаи и традиции были объявлены «пережитками прошлого», «патриархально-отсталыми», вместо них пропагандировались и усиленно внедрялись новые общественные коллективистские нормы и порядки социалистического общежития.

Однако опасность представляли не сами новые нормы и правила, многие из которых действительно содержали прогрессивные начала, так как были частью общей назревшей модернизации, продиктованной временем. Главную опасность преобразований этого периода представляла их тотальность, не оставлявшая места альтернативе, индивидуальной свободе личности, деформировавшая естественный процесс этнического развития народа. По мере укрепления нового строя в культурном строительстве все больше становятся доминирующими, а затем и господствующими идеологическая направленность и политическая целесообразность. В мае 1929 г. Буручком из главного координирующего научного центра, имевшего, кроме научных, еще и административные функции, был преобразован в Государственный институт культуры, задачи которого ограничивались научно-исследовательской работой в области истории, языка и литературы.

В ноябре 1930 г. на республиканском партийном совещании была полностью осуждена принятая ранее установка в области языковой политики, ориентированная на создание бурятского литературного языка на основе халхаского наречия и старомонгольской письменности. Все буддийское духовное наследие было признано реакционным и не имеющим ничего общего с бурятской национальной культурой, а ориентация на «фреодальнотеократическую» культуру Монголии и Тибета расценивалась как проявление правого оппортунизма, местного национализма и контрреволюционного панмонголизма.

Объединенный пленум ОК и ОКК ВКП(б), состоявшийся в сентябре 1931 г., развивая решения ЦК, сфрормулировал курс на строительство социалистической по содержанию и национальной по форме культуры бурятского народа. Прежде всего, перед институтом культуры (бывшим Буручкомом) ставилась задача выработки нового литературного языка на основе одного из живых диалектов бурятского языка. В 1931 г. бурятский язык был переведен на латинский алфравит, а за основу литературного языка был взят селенгинский диалект. Однако эта реформа не дала положительного результата, так как, по мнению ее критиков, не обеспечила сближения литературного языка с разговорным языком большинства, поэтому в дальнейшем пришлось продолжить его преобразования. В 1936 г. литературный язык был сориентирован на хоринский диалект, а в 1939 г. был принят русский алфравит с добавлением трех букв для обозначения специфических звуков бурятского языка. Неоднократные реформы бурятского языка в период его становления, безусловно, имели негативные последствия в дальнейшем. Наметился разрыв в культурных традициях, наследие прошлых поколений постепенно становилось недоступным для широких масс народа. В настоящее время большинство бурятских ученых-языковедов (И.Д. Бураев, Л.Д. Шагдаров, У.Ж.Ш. Дондуков, Г.А. Дырхеева, В.В. Базарова и др.) связывают проблемы современного бурятского языка с необдуманными реформами в 1920-1930-е гг.

Тем не менее, была проведена значительная работа в области народного образования, которая не могла не сказаться на росте грамотности населения республики. С 1930 г. начал осуществляться переход к всеобщему начальному образованию. Расширялась сеть школ, укреплялась их материальная база, увеличивалось количество учащихся. 
Таблица 1. Грамотность русского и бурятского населения БМАССР по переписям 1926 и 1939 гг. ${ }^{5}$

\begin{tabular}{|l|c|c|}
\hline & $\mathbf{1 9 2 6}$ г. & $\mathbf{1 9 3 9}$ г. \\
\hline Городское население & $\mathbf{7 7 , 1}$ & 86,7 \\
\hline Русские & 77,2 & 86,8 \\
\hline В Т.ч. мужчины & 86,9 & 94,3 \\
\hline Женщины & 65,0 & 78,8 \\
\hline Буряты & 71,1 & 85,7 \\
\hline В т.ч. мужчины & 73,2 & 91,0 \\
\hline Женщины & 63,9 & 79,7 \\
\hline Сельское население & 33,6 & 71,8 \\
\hline Русские & 39,4 & 74,6 \\
\hline В т.ч. женщины & 22,6 & 62,8 \\
\hline Мужчины & 56,6 & 86,6 \\
\hline Буряты & 25,3 & 65,5 \\
\hline В т.ч. мужчины & 43,9 & 76,4 \\
\hline Женщины & 7,2 & 58,2 \\
\hline
\end{tabular}

Средства, вложенные в народное образование, способствовали тому, что в 1940 г. грамотность населения Бурятии поднялась до 90\%. Следствием этого процесса стал приток новых молодых кадров в вузы республики. К концу 1930-х гт. уже сложилась система подготовки специалистов народного хозяйства, в том числе высшей квалификации.

В ходе культурного строительства в условиях аграрной республики особое внимание было уделено культурным преобразованием на селе. К 1940-м гг. совершенно изменился образовательный облик региона, что стало следствием целенаправленной культурно-просветительной работы властей, пытавшихся таким путем поднять грамотность и техническую подготовку населения, сфрормировать его политическую ориентацию. Вместе с тем, следует учитывать и тот фракт, что разительные перемены, происходившие в духовной сфере, столкнулись с противоречивостью новой политической системы, требовавшей такого типа художника, писателя, музыканта, который бы всецело руководствовался идеологическими ценностями, отстаивал классовость и партийность искусства. Поэтому в многочисленных дискуссиях того времени вопрос о классовых целях искусства приоритетно выдвигался на первый план, а забота об идейной чистоте возлагалась на пролетарскую партию. Если еще в 1920-е гг. было распространено мнение, что «область искусства есть такая ссрера, где партия не должна командовать, а призвана лишь косвенно руководить», то к концу 1930-х гг. все кардинально изменилось. Были репрессированы все те, кого официальное руководство партии большевиков отнесло к оппозиционерам. Для руководителей партии и правительства общим стало положение о том, что история приведет различные группы интеллигенции на позиции марксизма, что вся интеллигенция станет советской, коммунистической. Вопрос стоял только о темпах, формах и методах данного перехода, непременно регулируемого, управляемого марксистской партией.

Коммунистический режим нуждался в расширении своей опоры среди непролетарских масс, в том числе находящихся в национальных регионах. В свою очередь, представители интеллигенции для развития своей профрессиональной деятельности также нуждались в поддержке власти. Перемены, происходившие в обществе, естественно, не могли не сказаться на

\footnotetext{
${ }^{5}$ При определении процентной грамотности населения взято количество грамотных в возрасте девяти лет и старше в процентах к общей численности населения этих же возрастных групп.
} 
поведении и политической ориентации национальной художественной интеллигенции, тем более что многие ее представители уже перешли на сторону советской власти. И здесь невозможно не согласиться с утверждением исследователя М.А. Шакирзянова, что «главным побудительным мотивом при этом явился тот факт, что пришедшие к власти большевики фрактически уравняли ее в правах с русской интеллигенцией, предложили не только молодым людям, но и представителям старшего и среднего поколения новые возможности» (Шакирзянов 1999: 45). Именно поэтому они и пытались увидеть в советской власти гаранта своего развития.

Таким образом, можно утверждать, что исторические и общественные условия региона, особенности бурятской провинции определяли специфику формирования художественной интеллигенции. Эти условия характеризовались, с одной стороны, воздействием центрально-азиатской культуры, буддизма. С другой, - влиянием материальной и духовной культуры русского населения. Достижения российской культуры облегчили процесс формирования бурятской национальной интеллигенции, позволили нивелировать многие неблагоприятные социально-экономические предпосылки ее развития.

Неблагоприятные условия, в которых проходило еe формирование определили мелкобуржуазную природу интеллигенции, близость к народу, естественный отбор при обучении, пополнение лучшими представителями народа, престижность образования, дававшего возможность повышения социального статуса.

Накануне революции бурятская национальная интеллигенция представляла собой вполне сложившуюся группу образованных людей, составлявших элиту бурятского народа, осознававшую свое предназначение. Малочисленность интеллигенции, сложившаяся политическая обстановка способствовали совмещению ее представителями различных видов деятельности: профессиональной, общественно-политической и творческой. Поэтому, говоря о художественной интеллигенции, мы говорим о национальной интеллигенции в целом.

Строительство новой национальной культуры осуществлялось в сложных условиях, при отсутствии практического опыта, необходимой материальной базы, научного и профессионально-кадрового обеспечения. Бурятская художественная интеллигенция прошла через все эксперименты, проводившиеся властью, в области развития национального языка, создания новой культуры и укрепления тоталитарного режима.

Вместе с тем, несмотря на противоречивый характер, а в некоторых случаях и негативные последствия в сфере культурного строительства, надо признать и бесспорные успехи в этой области. Усилиями партийногосударственных органов республики в сжатые сроки при поддержке советских и партийных органов страны были коренным образом изменены духовные и социальные условия развития бурятского народа. В этот период была ликвидирована неграмотность населения, заложены основы системы образования и здравоохранения, были созданы научные, высшие и средние специальные учебные заведения, учреждения искусства и культуры, подготовлены кадры новой бурятской национальной интеллигенции, в том числе и художественной.

Әдебиеттер тізімі / Список литературы

1. Андреев А.И. Буддийские святыни Петрограда. -Улан-Удэ, 1992.

2. Басаев Г.Д., Ербанова С.Я. М.Н. Ербанов. -Улан-Удэ, 1989. 
3. Батуев Б.Б. К вопросу о характере национального движения в Бурятии // Октябрьская революция и гражданская война в Сибири и на Дальнем Востоке - Улан-Удэ: Сибирь, 1993.

4. Бильтрикова А.В. Бурятская национальная интеллигенция на современном этапе. - УланУдэ: Изд-во БНЦ СО РАН, 2001.

5. Бурятская организация КПСС. Хроника. Т. 1. - Улан-Удэ, 1987.

6. Бурятская этничность в контексте социокультурной модернизации (конец XIX - первая треть XX веков). - Иркутск, 2003.

7. Герасимова К.М. О бурятской и буржуазной интеллигенции XX века // Герасимова К.М. Национальная интеллигенция, духовенство и проблемы социального, национального возрождения народов Республики Бурятия. - Улан-Удэ, 1995.

8. Гирченко В.П. Этапы революционного движения в Бурятии 1917-1918 гг. (Хроника). Верхнеудинск: Изд-во журнала «Жизнь Бурятии», 1927.

9. Дондуков У.-Ж. Ш. К вопросу о развитии бурятского литературного языка // Проблемы истории и культурно-национального строительства в Республике Бурятия. Матер. респ. науч.практ. конф. - Улан-Удэ, 1998.

10. Елаев А.А. Бурятский народ: становление, развитие, самоопределение. - М., 2000.

11. Ербанов М.Н. Вопросы культурно-национального строительства в Бурятии. Краткий очерк. Верхнеудинск, 1926.

12. История и культура бурятского народа. - Улан-Удэ: Бэлиг, 1999.

13. КПСС в резолюциях и решениях съездов, конференций и пленумов ЦК. Ч. І. - М., Гос. изд-во полит. литературы. 1953.

14. Маляревский П. Очерк из истории театральной культуры Сибири. - Иркутск, 1957. - С. 45-82.

15. «Отчий край»: краеведческий сборник. - Улан-Удэ. 1993.

16. Ринчино Э.-Д. Документы, статьи, письма. - Улан-Удэ, 1994.

17. Санжиев Г.Л. В.И. Ленин и национально-государственное строительство в Сибири (1917-1937 гг.). -Улан-Удэ, 1971.

18. Соктоев И.А. Формирование социалистической интеллигенции в Бурятии. -Улан-Удэ: Бур. кн. изд-во, 1961.

19. Социалистическое строительство Бурятии за 10 лет. - Верхнеудинск, 1933.

20. Очерки истории Бурятской организации КПСС. - Улан-Удэ: Бур. кн. изд-во, 1970.

21. Танский М.В. Странички из прошлого Улан-Удэ. - Улан-Удэ, 1963.

22. Цыбиков Г.Ц., Барадин Б.Б., Дамбинов П.М. Материалы к І-му культурно-национальному совещанию. - Верхнеудинск, 1926.

23. Шакирзянов М.А. Национальная художественная интеллигенция и власть в Татарстане: проблема взаимоотношений в 1920-1930-е гг. Дисс. канд. ист. наук. - Казань, 1999.

\section{References}

Andreev 1992 - Andreev, Al 1992, Buddijskie svyatyni Petrograda, Ulan-Ude. (Andreev, Al 1992, Buddhist Shrine of Petrograd, Ulan-Ude). (in Rus).

Basaev, Erbanova, Erbanov 1989 - Basaev, GD, Erbanova, SYa, 1989, M.N. Erbanov, Ulan-Ude. (Basaev, GD, Erbanova, SYa, 1989, M.N. Erbanov, Ulan-Ude). (in Rus).

Batuev 1993 - Batuev, BB 1993, K voprosu o haraktere nacional'nogo dvizheniya v Buryatii, Oktyabr'skaya revolyuciya i grazhdanskaya vojna v Sibiri i na Dal'nem Vostoke, Sibir', Ulan-Ude. (Batuev, BB 1993, On the nature of the national movement in Buryatia, October revolution and the civil war in Siberia and the far East, Sibir', Ulan-Ude.). (in Rus).

Bil'trikova 2001 - Bil'trikova, AV 2001, Buryatskaya nacional'naya intelligenciya na sovremennom ehtape, Izd-vo BNC SO RAN, Ulan-Ude, S. 27. (Bil'trikova, AV 2001, Buryat national intelligentsia at the present stage, Izd-vo BNC SO RAN, Ulan-Ude, P. 27). (in Rus).

Buryatskaya ehtnichnost' 2003 - Buryatskaya ehtnichnost' v kontekste sociokul'turnoj modernizacii (konec XIX-pervaya tret' XX vekov) 2003, Irkutsk. (Buryat ethnicity in the context of socio-cultural modernization (late XIX-first third of XX centuries) 2003, Irkutsk). (in Rus).

Buryatskaya organizaciya 1987 - Buryatskaya organizaciya KPSS. Hronika 1987, T. 1, Ulan-Ude. (Buryat organization of the CPSU. Chronicle 1987, T. 1, Ulan-Ude). (in Rus).

Cybikov, Baradin, Dambinov 1926 - Cybikov, GC, Baradin, BB, Dambinov, PM 1926, Materialy k 1-mu kul'turno-nacional'nomu soveshchaniyu, Verhneudinsk. (Cybikov, GC, Baradin, BB, Dambinov, PM 1926, Materials for the I-th cultural and national meeting, Verhneudinsk). (in Rus).

Dondukov 1998 - Dondukov, U.-Zh.Sh 1998, K voprosu o razvitii buryatskogo literaturnogo yazyka, Problemy istorii i kul'turno-nacional'nogo stroitel'stva v Respublike Buryatiya. Mater. resp. nauch.prakt. konf., Ulan-Ude. (Dondukov, U.-Zh.Sh 1998, To the question about the development of the Buryat literary language, The Problems of history and national cultural construction in the Republic of Buryatia. Mater. resp. scientific.-prakt. conf., Ulan-Ude). (in Rus).

Elaev 2000 - Elaev, AA 2000, Buryatskij narod: stanovlenie, razvitie, samoopredelenie, Moscow. (Elaev, AA 2000, Buryat people: formation, development, self-determination, Moscow). (in Rus). 
Erbanov 1926 - Erbanov, MN 1926, Voprosy kul'turno-nacional'nogo stroitel'stva v Buryatii. Kratkij ocherk, Verhneudinsk. (Erbanov, MN 1926, Issues of cultural and national construction in Buryatia. Brief sketch, Verhneudinsk). (in Rus).

Gerasimova 1995 - Gerasimova, KM 1995, O buryatskoj i burzhuaznoj intelligencii XX veka, Gerasimova, KM Nacional'naya intelligenciya, duhovenstvo i problemy social'nogo, nacional'nogo vozrozhdeniya narodov Respubliki Buryatiya, Ulan-Ude. (Gerasimova, KM 1995, On the Buryat and bourgeois intelligentsia of the XX century, National Intelligation, clergy and problems of social, national revival of the peoples of the Buryatia Republic, Ulan-Ude). (in Rus).

Girchenko 1927 - Girchenko, VP 1927, Etapy revolyucionnogo dvizheniya v Buryatii 1917-1918 gg. (Hronika) 1927, izd-vo zhurnala «ZHizn' Buryatii», Verhneudinsk. (Girchenko, VP 1927, Stages of the revolutionary movement in Buryatia, 1917-1918 (Chronicle) 1927, Punlishing house of the journal «ZHizn' Buryatii», Verhneudinsk). (in Rus).

Istoriya i kul'tura 1999 - Istoriya i kul'tura buryatskogo naroda 1999, Behlig, Ulan-Ude. (History and culture of the Buryat people 1999, Behlig, Ulan-Ude). (in Rus).

KPSS v rezolyuciyah i resheniyah 1953 - KPSS v rezolyuciyah i resheniyah s"ezdov, konferencij i plenumov CK 1953, Ch. I, Gos. izd-vo polit-oj lit-ry, Moscow. (The CPSU resolutions and decisions of congresses, conferences and plenums of the Central Committee 1953, Ch. I, Gos. izd-vo polit-oj lit-ry, Moscow). (in Rus).

Malyarevskij 1957 - Malyarevskij, P 1957, Ocherk iz istorii teatral'noj kul'tury Sibiri, Irkutsk, S. 45-82. (Malyarevskij, P 1957, Sketch of the history of theatrical culture of Siberia, Irkutsk, S. 45-82). (in Rus).

Ocherki istorii 1970 - Ocherki istorii Buryatskoj organizacii KPSS 1970, Bur. kn. izd-vo, Ulan-Ude. (Essays on the history of The Buryat organization of the CPSU 1970, Bur. kn. izd-vo, Ulan-Ude). (in Rus).

Otchij kraj 1993 - Otchij kraj: Kraevedcheskij sbornik 1993, Sost. Golubev, EA, Sodnomov, AA, UlanUdeh, S. 41-42. (Fatherland: Collection of local lore 1993, Compilers Golubev, EA, Sodnomov, AA, Ulan-Udeh, P. 41-42). (in Rus).

Rinchino 1994 - Rinchino, ED 1994, Dokumenty, stat'i, pis'ma, Ulan-Ude. (Rinchino, ED 1994, Documents, articles, letters, Ulan-Ude). (in Rus).

Sanzhiev 1971 - Sanzhiev, GL 1971, V.I. Lenin i nacional'no-gosudarstvennoe stroitel'stvo v Sibiri (1917-1937 gg.), Ulan-Ude. (Sanzhiev, GL 1971, V.I. Lenin and the national-state building in Siberia (1917-1937 years.), Ulan-Ude). (in Rus).

Shakirzyanov 1999 - Shakirzyanov, MA 1999, Nacional'naya hudozhestvennaya intelligenciya $i$ vlast' v Tatarstane: problema vzaimootnoshenij v 1920-1930-e gg: Diss. kand. ist. Nauk, Kazan'. (Shakirzyanov, MA 1999, National art intellectuals and power in Tatarstan: the problem of the relationship in the 1920s-1930s: Diss. kand. history sciences, Kazan'). (in Rus).

Socialisticheskoe stroitel'stvo 1933 - Socialisticheskoe stroitel'stvo Buryatii za 10 let 1933, Verhneudinsk. (Socialist construction in Buryatia Republic for 10 years 1933, Verhneudinsk). (in Rus).

Soktoev 1961 - Soktoev, IA 1961, Formirovanie socialisticheskoj intelligencii v Buryatii, Bur. kn. izd-vo, Ulan-Ude. (Soktoev, IA 1961, Formation of the socialist intelligentsia in Buryatia, Bur. kn. izd-vo, Ulan-Ude). (in Rus).

Tanskij 1963 - Tanskij, MV 1963, Stranichki iz proshlogo Ulan-Ude, Ulan-Ude, 1963. (Tanskij, MV 1963, Pages from the past Ulan-Ude, Ulan-Ude, 1963). (in Rus). 